\title{
Energy Savings by means of Energy Efficient Electric Motors
}

\author{
S. Corino E. Romero L.F. Mantilla \\ Department of Electrical Engineering and Energy \\ E.T.S.I.I. y T. Universidad de Cantabria \\ Avda de Los Castros, 39005 Santander (Spain)
}

phone:+34 942 201381, fax:+34 942 201381, e-mail: mantillf@unican.es

\begin{abstract}
The electric motors consume a significant amount of electricity in the industrial and in the tertiary sectors of the European Union. Because of its simplicity and robustness the three-phase squirrel-cage induction motor is the prime mover of the modern industry. The electricmotor manufacturers are seeking methods for improving the motor efficiencies, which resulted in a new generation of electric motors that are known as energyefficient motors.

This paper deals with energy conservation by installing energy efficient motor (EEM) instead of standard efficiency motor. This transition becomes a necessity as a direct result of limitation in energy sources and escalating energy prices. In the end of this analysis, there are different practical cases in where EEM is compared with standard motors and rewound motor. In all these cases energy savings can be achieved and the simple payback is less of five years. So, it is very interesting the implementation of EEM in the industry.
\end{abstract}

Keywords: energy efficiency, induction motor, energy saving.

Code: 250-mantilla

\section{Introduction}

In the future, the cost of energy will increase due to environmental problems and limited resources. The electric motors consume a major part of the electric energy in the industry. The induction motor is the main driven system in the modern industrial society.

Implementing energy efficient motor could save Europe a significant amount of electricity. It would also reduce the production of greenhouse gases and push down the total environmental cost of electricity generation. Also these motors can reduce maintenance costs and improve operations in industry.

\section{Characterisation of Electricity Use in UE}

The next countries: France, Germany, Spain and Portugal, Italy, Netherlands, Scandinavia and United Kingdom represent about $89 \%$ of the consumption of all the EU countries [1], and it can be seen in the next figure:

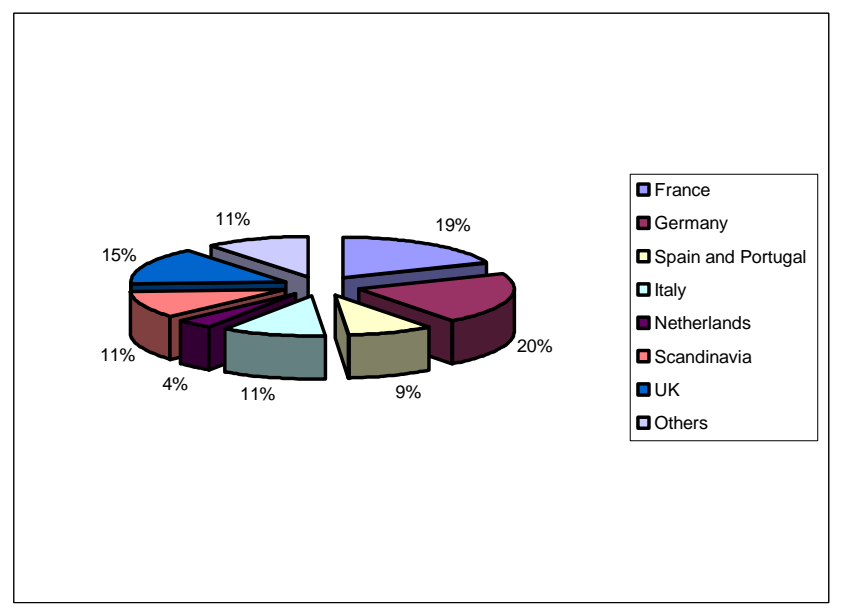

Figure 2.1 - Share of Electricity Consumption in European Union Countries. It is based on 2010 Consumption Forecast [1]

It can be done a distribution of electricity of the most important industrial sectors in the UE. In order to carry out this distribution, it is going to be taken into account the importance of each industry in these countries. The information gathered is extrapolated for the $\mathrm{EU}$ and shown in figure 2.2.

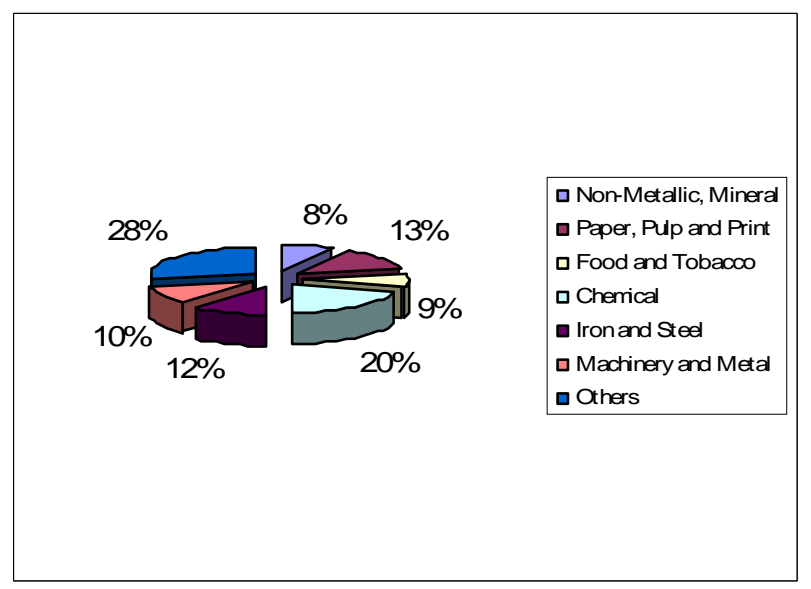

Figure 2.2 - Disaggregation of the industrial electricity consumption by industrial sector [2].

Europe has a great dependence on energy; therefore it is an important goal the promotion of energy efficient motors to be applied in the industry. 


\section{Energy Efficient Motor (EEM)}

\section{A. Definition}

An EEM produces the same shaft output power, but uses less input power than a standard efficiency motor.

A standard motor is a compromise between efficiency, endurance, starting torque, and initial cost (with strong emphasis on the initial cost). Standard motor generally competes on price, not efficiency. On the contrary, EEM competes on efficiency, not price.

There are a lot of terms in order to name this kind of motors, for example "energy efficient", “efficiency premium" or "energy saving". In order to clarify this situation, CEMEP (the European Committee of Manufacturers of Electrical Machines and Power Electronics) and the European Commission have devised motor efficiency classification labels - Eff1, Eff2 y Eff3 - to make it much easier for purchasers to identify energy efficient motors on the market. The programme was implemented by a voluntary agreement between the Commission and the motor manufacturers to reduce sales of Eff3 motors by half by 2003. That target has been reached. Figure 3.1 relates the efficiencies for these types of motors.

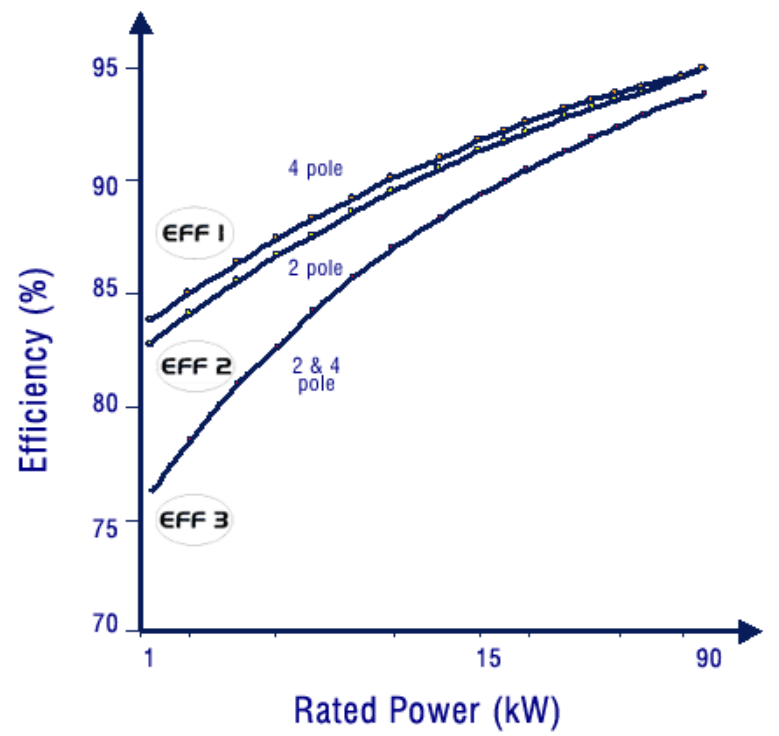

Figure 3.1 - Curves Efficiency-Rated Power [3].

The term energy efficient is preferred by manufacturers in USA because it is recognized by NEMA as defined in NEMA Standards Publication MG 1-1993 Motors and Generators, and because it most clearly describes the feature of interest: energy efficiency.

\section{B. Constructive description}

EEM is manufactured using the same frame as a standard motor, but they have some differences:
- Higher quality and thinner steel laminations in the stator.

- More copper in the windings.

- Optimized air gap between the rotor and the stator.

- $\quad$ Reduced fan losses.

- Closer machining tolerances.

- A greater length.

- $\quad$ High quality aluminium used in rotor frame.

\section{Advantages}

- The EEM has a greater efficiency than a standard motors; therefore they have less operating costs.

- EEM has a lower slip so they have a higher speed than standard motors.

- EEM can reduce maintenance costs and improve operations in industry due to robustness and reliability.

- $\quad$ Increasing the productivity.

D. Recommendations when applying EEM

EEM should be considered in the following cases:

- For all new installations.

- When major modifications are made to existing facilities or processes.

- For all new purchases of equipment packages that contain electric motors.

- When purchasing spares or replacing failed motors.

- Instead of rewinding old standard motors.

- $\quad$ To replace grossly oversized and under loaded motors.

- As a part of an energy management or preventive maintenance program.

- When utility conservation programs, rebates or incentives are offered that make energy efficient motor retrofits cost-effective.

\section{E. Benefits when implementing Energy Efficient Motor}

Switching to energy efficient motor driven system can save Europe up to 202 billion kWh in electricity consumption, equivalent to a reduction of $10 €$ billion per year in operating costs for industry.

The beneficiaries of their advantages are the industries because they improve their processes and reduce their costs; but society also is other beneficiary due to reduction of $\mathrm{CO}_{2}$ emissions.

\begin{tabular}{|c||c||c|}
\hline Benefit & Beneficiary & $\begin{array}{c}\text { Annual Benefit (€ } \\
\text { billion) }\end{array}$ \\
\hline \hline Energy cost saving & Industry & 10 \\
\hline $\begin{array}{c}\text { Non-energy saving } \\
\text { benefits }\end{array}$ & Industry & $5-10$ \\
\hline \hline $\begin{array}{c}\text { Reduced } \\
\text { environmental } \\
\text { costs }\end{array}$ & Society & 6 \\
\hline
\end{tabular}


Table 3.1 - Benefits of switching to energy efficient motor driven systems [4].

\section{1) Electricity savings potential}

Motor driven systems consume about $65 \%$ of industrial electricity in the European Union. It is possible to calculate economical savings potential of 27 billion $\mathrm{kWh}$ per year or $4.33 \%$. This means a savings potential of more than $1.04 \%$ of the overall electricity consumption in the EU [4].

\begin{tabular}{||c||c||c||c||c||c||}
\hline \multicolumn{6}{|c||}{ Savings potential (billion kWh/year) } \\
\hline \hline $\begin{array}{c}\text { Energy } \\
\text { Efficient } \\
\text { Motor }\end{array}$ & EU & France & Germany & Italy & UK \\
\cline { 2 - 6 } & 4 & 4 & 6 & 4 & 3 \\
\hline
\end{tabular}

Table 3.2 - Overview of energy savings potential in the EU [4].

\section{2) Environmental benefits}

One of the major current environmental concerns is the greenhouse gas emissions $\left(\mathrm{CO}_{2}, \mathrm{~N}_{2} \mathrm{O} \ldots\right)$. After signing the Kyoto protocol, it must reduce overall greenhouse gas emissions over the period 2008 to 2012 by $8 \%$ or 336 million tonne $\mathrm{CO}_{2}$ equivalent. The energy efficient motor can contribute in order to achieve this target. Representatives of 190 countries have met in Bali (4ht December of 2007) to look for a protocol against environmental change in order to replace Kyoto protocol when it expires in 2012.

\begin{tabular}{||c||c||c||c|c|c||}
\hline & EU & France & Germany & Italy & UK \\
\hline $\begin{array}{c}\text { Reduction } \\
\text { potential } \\
\text { for } \\
\text { greenhouse } \\
\text { gas } \\
\text { emissions } \\
\text { (Million } \\
\text { tonne } \mathrm{CO}_{2} \\
\text { per year) }\end{array}$ & 100 & 3 & 27 & 14 & 12 \\
\hline $\begin{array}{c}\text { \% of } \\
\text { Kyoto gap }\end{array}$ & - & $6 \%$ & $175 \%$ & $26 \%$ & - \\
\hline \hline
\end{tabular}

Table 3.3 - Overview of the $\mathrm{CO}_{2}$ reduction potential for efficient motor systems [4].

\section{3) Micro economical benefits}

The micro economical benefits are non-energy benefits that achieve due to implementing energy efficient motors such as:

- A better process control.

- A reduced disruption process.

- An improved product quality.

- Sometimes reliability is improved.

4) Macro economical benefits It is possible to consider three direct macro economical benefits:

- Increased competitiveness.
- $\quad$ Raised employment.

- $\quad$ Reduced dependency of fossil fuels.

Using energy as efficiently as possible is a crucial requirement to maintain the competitiveness of the European economy.

The investments in energy efficient motors can create jobs in three areas: energy service companies, manufacturers of motors and jobs in energy or maintenance departments.

\section{F. Fixing common mistakes}

There are many misunderstandings about the characteristics of energy efficient motors. Some of them lead users to expect more than they will deliver. For example:

- An oversized motor is less efficient.

- A more efficient motor also has higher power factor.

- $\quad$ More efficient motors run cooler.

- An energy efficient motor develops less torque, and may not accelerate the load.

\section{G. Economical Evaluation}

Generally, energy efficient motors cost an average 15 to 30 percent more than standard motors, but it depends on the specific motor manufacturers and market competition. It is often possible to obtain a lower price premium when purchasing a large quantity of energy efficient motors. The price premium per horsepower is lower for the large motor ratings.

The next figure shows the different prices between an energy efficient motor and a standard motor.

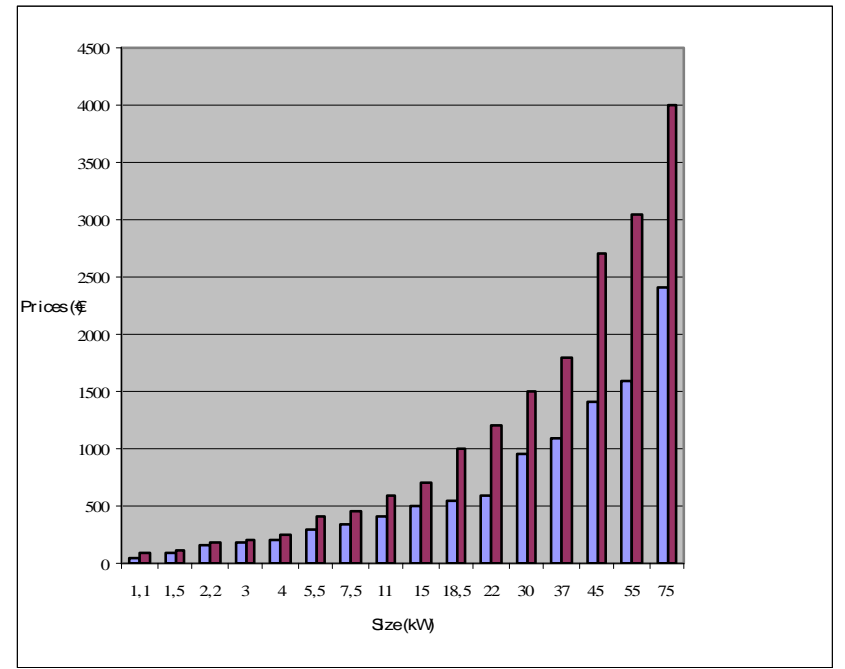

Figure 3.2 - Average sales-weighted prices in the EU [5]. 
An energy efficient motor is always more expensive than a standard motor, and this difference increases with the size.

The payback period varies according to the purchase scenario under consideration, cost difference, hours of operation, electrical rates, motor loading and difference in motor efficiencies. For new purchase decisions or the replacement of burned-out and unrewindable motors, the simple payback period for the extra investment associated with an energy efficient motor purchase is the ratio of the price premium less any available utility rebate, to the value of the total annual electrical savings.

Simple payback years $=\frac{\text { Price premium }- \text { utility rebate }}{\text { Total annual } \cot s \text { savings }}$

For replacements of operational motors, the simple payback is the ratio of the full cost of purchasing and installing a new energy efficient motor relative to the total annual electrical savings.

Simple payback years $=$

New motor cos $t+$ installation ch arg $e-$ utility rebate

Total annual cos $t$ savings

\section{Practical Cases}

The software EURODEEM International is going to be used in order to develop different practical cases.

\section{A. Case $n^{\circ}$ 1: A new purchase of energy efficient motor}

A new energy efficient motor (Eff1) is going to be bought and it is compared with a motor Eff2. Their size and speed are $55 \mathrm{~kW}$ and $1500 \mathrm{rpm}$, respectively. It assumes a $75 \%$ load.

\begin{tabular}{|c|c|c|}
\hline & Eff2 & Eff1 \\
\hline Efficiency (\%) & 93.2 & 94.6 \\
\hline $\begin{array}{c}\text { Differential cost } \\
(€)\end{array}$ & - & 1071 \\
\hline $\begin{array}{l}\text { Energy use } \\
\text { (kWh/year) }\end{array}$ & 265533 & 261540 \\
\hline $\begin{array}{c}\text { Energy cost } \\
(€ / \text { year }) \\
\end{array}$ & 13277 & 13077 \\
\hline $\begin{array}{c}\text { Demand charge } \\
(€ / \text { year })\end{array}$ & 2655 & 2615 \\
\hline \multicolumn{3}{|c|}{ Energy Savings } \\
\hline $\begin{array}{c}\text { Energy } \\
\text { (kWh/year) }\end{array}$ & - & 3993 \\
\hline Demand $(\mathrm{kW})$ & 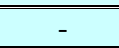 & 0.7 \\
\hline $\begin{array}{c}\text { Energy savings } \\
\text { (€/year) }\end{array}$ & - & 200 \\
\hline $\begin{array}{c}\text { Demand savings } \\
(€ / \text { year })\end{array}$ & - & 40 \\
\hline Total saving & - & 240 \\
\hline
\end{tabular}

\begin{tabular}{|c||c||c|}
\hline (€/year) & & \\
\hline \hline $\begin{array}{c}\text { Simple payback } \\
\text { (years) }\end{array}$ & - & 4,47 \\
\hline \hline
\end{tabular}

B. Case $n^{\circ}$ 2: Replacing existing motor with smaller energy efficient motor

An old standard motor (Eff3) of size of $90 \mathrm{~kW}$ and speed of $3000 \mathrm{rpm}$ is going to be replaced by an energy efficient motor of size of $75 \mathrm{~kW}$ and the same speed. They are operating $75 \%$ load.

\begin{tabular}{|c|c|c|}
\hline & Eff3 & Eff1 \\
\hline Efficiency (\%) & 92.1 & 94.8 \\
\hline $\begin{array}{c}\text { Differential cost } \\
(€)\end{array}$ & - & 4074 \\
\hline $\begin{array}{l}\text { Energy use } \\
\text { (kWh/year) }\end{array}$ & 439835 & 356148 \\
\hline $\begin{array}{c}\text { Energy cost } \\
(€ / \text { year })\end{array}$ & 21992 & 17807 \\
\hline $\begin{array}{c}\text { Demand charge } \\
(€ / \text { year })\end{array}$ & 4398 & 3561 \\
\hline \multicolumn{3}{|c|}{ Energy Savings } \\
\hline $\begin{array}{c}\text { Energy } \\
\text { (kWh/year) }\end{array}$ & - & 83687 \\
\hline Demand $(\mathrm{kW})$ & - & 13.9 \\
\hline $\begin{array}{l}\text { Energy savings } \\
\text { (€/year) }\end{array}$ & - & 4184 \\
\hline $\begin{array}{c}\text { Demand savings } \\
(€ / \text { year })\end{array}$ & - & 837 \\
\hline $\begin{array}{c}\begin{array}{c}\text { Total saving } \\
\text { (€/year) }\end{array} \\
\end{array}$ & - & 5021 \\
\hline $\begin{array}{c}\text { Simple payback } \\
\text { (years) }\end{array}$ & - & 0.81 \\
\hline
\end{tabular}

C. Case $n^{\circ}$ 3: Replacing existing motor with same-sized energy efficient motor

An old standard motor (Eff3) of size of $75 \mathrm{~kW}$ and speed of $3000 \mathrm{rpm}$ is going to be replaced by an energy efficient motor of the same size and the same speed. They are operating 75\% load.

\begin{tabular}{|c||c||c||}
\hline & Eff3 & Eff1 \\
\hline \hline Efficiency (\%) & 90.0 & 94.8 \\
\hline \hline $\begin{array}{c}\text { Differential cost } \\
(€)\end{array}$ & - & 4074 \\
\hline \hline $\begin{array}{c}\text { Energy use } \\
(\mathrm{kWh} / \text { year })\end{array}$ & 371369 & 356148 \\
\hline \hline $\begin{array}{c}\text { Energy cost } \\
(€ / \text { year) }\end{array}$ & 18568 & 17807 \\
\hline \hline $\begin{array}{c}\text { Demand charge } \\
(€ / \text { year) }\end{array}$ & 3714 & 3561 \\
\hline \hline \multicolumn{2}{|c|}{ Energy Savings } \\
\hline \hline $\begin{array}{c}\text { Energy } \\
(\mathrm{kWh} / \text { year })\end{array}$ & - & 15221 \\
\hline
\end{tabular}




\begin{tabular}{||c||c|c||}
\hline Demand (kW) & - & 2.5 \\
\hline \hline $\begin{array}{c}\text { Energy savings } \\
\text { (€/year) }\end{array}$ & - & 761 \\
\hline \hline $\begin{array}{c}\text { Demand savings } \\
\text { (€/year) }\end{array}$ & - & 152 \\
\hline \hline $\begin{array}{c}\text { Total saving } \\
\text { (€/year) }\end{array}$ & - & 913 \\
\hline \hline $\begin{array}{c}\text { Simple payback } \\
\text { (years) }\end{array}$ & - & 4.46 \\
\hline
\end{tabular}

\section{Case $n^{\circ}$ 4: Rewinding}

A rewound standard motor (Eff3) of size of $75 \mathrm{~kW}$ and speed of $3000 \mathrm{rpm}$ is going to be compared by an energy efficient motor of the same size and the same speed. They are operating 75\% load.

\begin{tabular}{||c|c|c||}
\hline & Eff3 & Eff1 \\
\hline \hline Efficiency (\%) & 90.4 & 94.8 \\
\hline $\begin{array}{c}\text { Differential cost } \\
(€)\end{array}$ & - & 2103 \\
\hline \hline $\begin{array}{c}\text { Energy use } \\
\text { (kWh/year) }\end{array}$ & 373423 & 356148 \\
\hline \hline $\begin{array}{c}\text { Energy cost } \\
\text { (€/year) }\end{array}$ & 18671 & 17807 \\
\hline $\begin{array}{c}\text { Demand charge } \\
\text { (€/year) }\end{array}$ & 3734 & 3561 \\
\hline \hline $\begin{array}{c}\text { Energy } \\
\text { (kWh/year) }\end{array}$ & Energy Savings & 17275 \\
\hline \hline Demand (kW) & - & 2.9 \\
\hline \hline $\begin{array}{c}\text { Energy savings } \\
\text { (€/year) }\end{array}$ & - & 1764 \\
\hline \hline $\begin{array}{c}\text { Demand savings } \\
(€ / \text { year) }\end{array}$ & - & 2.02 \\
\hline \hline $\begin{array}{c}\text { Total saving } \\
\text { (€/year) }\end{array}$ & - & 1036 \\
\hline \hline $\begin{array}{c}\text { Simple payback } \\
\text { (years) }\end{array}$ & - & \\
\hline \hline
\end{tabular}

\section{Conclusions}

The analysis presented shows that energy efficient motors are an opportunity for improving the efficiency of motor systems, leading to large cost-effective energy savings, improving of the industrial economic efficiency and reducing the environmental impacts.

In spite of their advantages, these motors find barriers in the market that stop their penetration a large scale. These barriers are being overcome thanks to different strategies such as education, training, financial incentives, labelling and others.

With the practical cases, it can be noticed that EEM is more efficient than standard motor and rewound motor. Also, energy savings can be achieved and the extra cost of their purchase can be regained in five years or less.
To sum up, this paper has tried to stress that energy efficient motors lead to save a very significant amount of energy.

\section{References}

[1] "Actions to promote Energy Efficient Electric Motors." Save Study. European Commission. October 1996. pp. 30-37

[2] A. T. De Almeida, P. Fonseca, H. Falkner et al. "Improving the Penetration of Energy Efficient Motors and Drives." Save Study. European Commission. 2000. pp. 7-11.

[3] EURODEEM International Software version 1.0.17, 2007. http://sunbird.jrc.it/energyefficiency/eurodeem/index.htm

[4] D. Chapman, A. T. De Almeida, H. De Keulenaer et al. "Energy Efficient Motor Driven Systems." European Copper Institute. Motor Challenge. Belgium. April 2004. pp. 1-5.

[5] H. Falkner, "Promoting High Efficiency Motors in Europe. The role of the copper Industry", ETSU. European Copper Institute, pp. 13-26, November 2000.

[6] G. A. McCoy et J. G. Douglass. "Energy Efficient Electric Motor. Selection Handbook." Bonneville Power Administration. Washington. April 1995. pp. 17-41.

[7] "Understanding Energy Efficiency Motors", Electrical Apparatus Service Association (EASA), pp. 12-14.

http://www.easa.com/ 